\title{
Pierwszy pitawal wegetariański, czyli o ilustracjach Emilii Dziubak do Horroru Madleny Szeligi
}

\section{Abstrakt:}

W artykule autorka skupia się na warstwie wizualnej książki Horror Madleny Szeligi z ilustracjami Emilii Dziubak, wydanej przez krakowskie wydawnictwo Gereon w 2017 roku. Jest to zbiór dwudziestu miniatur literackich opisujących tragiczne losy siedemnastu różnych gatunków warzyw i owoców, a także pieczarek, słonecznika i pokrzyw, na co dzień traktowanych przez ludzi jako produkty spożywcze, a tu przedstawionych jako żyjące, a zatem czujące osobniki. Książka w interesujący sposób odnosi się do wielowiekowej tradycji obrazowania śmierci, męczeństwa i cierpienia oraz popularnych zwłaszcza w epoce baroku wątków wanitatywnych, bardziej niż do rekwizytorium horroru. Jako gatunek bowiem horror jest dobrze osadzony w literaturze i filmie, ale nie w refleksji nad sztukami plastycznymi. W artykule przedstawiono zatem inspiracje europejskim malarstwem nowożytnym, zarówno religijnym, alegorycznym, jak i martwymi naturami, a także epitafiami oraz ornamentem barokowym, twórczo wykorzystanymi przez ilustratorkę. Autorka wskazuje także na tradycję animizowania roślin wywodzącą się z europejskiej XIX-wiecznej ilustracji książkowej.

Słowa kluczowe:

barok, Emilia Dziubak, Horror, ilustracja książkowa dla dzieci, Madlena Szeliga, martwa natura, vanitas

\section{The First Vegetarian Pitaval - Emilia Dziubak's Illustrations to Horror by Madlena Szeliga}

\section{Abstract:}

In the article, the author focuses on the visual aspects of the book entitled Horror, written by Madlena Szeliga and illustrated by Emilia Dziubak, published by Gereon from Krakow in 2017. It is a collection of twenty literary miniatures

* Anita Wincencjusz-Patyna - dr, pracuje w Katedrze Historii Sztuki i Filozofii na Wydziale Malarstwa i Rzeźby Akademii Sztuk Pięknych im. Eugeniusza Gepperta we Wrocławiu. Jej zainteresowania obejmują historię i teorię ilustracji książkowej, a także historię dizajnu, zwłaszcza XX-wiecznego w Polsce. Kontakt: a.wincencjusz@asp.wroc.pl. 
which describe the tragical fate of seventeen different species of vegetables and fruit, and also champignons, a sunflower, and nettles, treated as food on a regular basis, whereas here they are depicted as living, and therefore feeling, specimens. The book makes interesting references to a centuries-old tradition of representing death, martyrdom, and suffering as well as vanitas threads popular especially in the period of Baroque rather than to a horror repertoire. For horror as a genre is quite well established in literature and film studies and not so much in fine arts research, the article discusses inspirations from Early Modern European painting, both religious, allegorical, and still life, as well as from Baroque epitaphs and ornamentation, very creatively used by the illustrator. The author of the article also underlines the tradition of animation and personification of plants which derives from the $19^{\text {th }}$-century European book illustration.

\section{Key words:}

Barouque, Emilia Dziubak, Horror, children's book illustration, Madlena Szeliga, still life, vanitas

orror, ściśle związany z fantastyką grozy, ma ugruntowaną pozycję w literaturze. Zrodzony z XVIII-wiecznej powieści gotyckiej, za dzieło prekursorskie mając Zamczysko w Otranto. Opowieść gotycka Horacego Walpole’a (1764/1976), rozwinął się w XIX stuleciu, zwłaszcza jako powieść grozy ${ }^{1}$, by pozostać do dzisiaj bardzo popularną odmianą prozy fantastycznej. Odbiorca dziecięcy horroru pojawił się z relatywnie niewielkim opóźnieniem, zaledwie pół wieku później, za sprawą Wilhelma i Jakuba Grimmów $(1812,1815)$, którzy publikując swoje zbiory baśni, zadedykowali je dzieciom ${ }^{2}$. W obszarze literatury dla dzieci i młodzieży opracowaniem zasługującym na szczególną uwagę, nie tylko ze względu na rzetelne potraktowanie wielowymiarowości poruszanej problematyki, lecz także liczne referencje do współczesnej humanistyki, jest książka Groza w literaturze dziecięcej. Od Grimmów do Gaimana Katarzyny Slany (2016). Horror jest także dobrze rozpoznanym przez badaczy gatunkiem filmowym, który swoje początki z przełomu XIX i XX wieku zawdzięcza Georges’owi Mélièsowi³

1 Por. definicje horroru, powieści gotyckiej i powieści grozy w Słowniku terminów literackich (Głowiński, Kostkiewiczowa, Okopień-Sławińska, Sławiński, 1976/1989, s. 186, 383, 384).

2 Problem odbiorcy baśni - „dorosły czy dziecko?”, związanej z tym gotowości małoletnich do przyjmowania pewnych treści, już choćby ze względu na rozwój psychiczny i pozyskane doświadczenie życiowe, jest złożony i poruszany przez wielu badaczy (np. Slany, 2016, s. 46-53; tam także dalsza literatura przedmiotu).

3 Więcej o kinie Georges'a Mélièsa piszą m.in. André Gaudreault (1995), Małgorzata Hendrykowska (1998) i Tadeusz Lubelski (2012). 
twórcy lubującemu się w diabolicznych, niesamowitych i groteskowych materiach. Tożsamość horroru filmowego wzmocnili swoimi dokonaniami ekspresjoniści niemieccy, m.in. Robert Wiene, Fritz Lange i Friedrich Wilhelm Murnau z jego kultowym filmem grozy Nosferatu - symfonia grozy (Dieckmann, Grau, Murnau 1922) ${ }^{4}$. Literaturoznawczyni i bibliolożka Anita Has-Tokarz (2010) pochyliła się nad obiema dziedzinami w pracy zatytułowanej Horror w literaturze współczesnej i filmie. Badaczka, wychodząc od zaproponowanej przez siebie definicji horroru, wskazuje na kryterium estetyczne, które winno w pierwszej kolejności decydować o rozpoznaniu tekstu jako przynależnego do horroru (s. 50).

Odnosząc się do estetyki, niejako śmielej można wkroczyć w obszar sztuk wizualnych (film), ale również sztuk plastycznych, w których kategoria horroru nie decyduje o przynależności genologicznej dzieł, co najwyżej odnosi się do atmosfery ewokowanej przez konkretną scenę. Historycy sztuki odwołują się raczej do pojęcia groteski (Gryglewicz, 1984) lub okropności, a przecież, jak zaskakująco, choć niezwykle trafnie zauważył Andrzej Pieńkos (2000) we wstępie do swojej książki poświęconej okropnościom sztuki nowoczesnej, „[sztuka dawna] była okropna, bo była sztuką" (s. 6). Wszak wystarczy spojrzeć na ociekające krwią przedstawienia malarskie, graficzne i rzeźbiarskie Pasji Chrystusa oraz męczeństwa świętych Pańskich torturowanych na najbardziej wymyślne sposoby - sceny obecne w sztuce od czasów średniowiecza. Jeśli doda się do tego występujące powszechnie w Europie wizje Apokalipsy, Sądu Ostatecznego, czeluści piekielnych i tortur, jakim poddawano grzeszników, następnie reprezentacje triumfu śmierci i danse macabre utrwalone przez epokę nowożytną, figury typu transi ukazujące rozkładające się ciało, popularne w sztuce sepulkralnej XIV-XVI wieku, ociekające krwią głowy po dekapitacji, nie tylko św. Jana Chrzciciela, lecz także Meduzy, Holofernesa czy ofiar wojen, obraz straszności i okrucieństw nadal będzie niepełny ${ }^{5}$. Jak w tym kontekście prezentuje się książka adresowana do dzieci ${ }^{6}$ pod tyleż lakonicznym, co elektryzującym tytułem Horror autorstwa Madleny Szeligi (2017) z ilustracjami Emilii Dziubak? W niniejszym artykule chciałabym się zająć przede wszystkim warstwą wizualną tej książki, która w interesujący sposób odnosi się do

4 Więcej o niemieckim filmie ekspresjonistycznym pisze Tomasz Kłys (2012).

5 Krótki przegląd niektórych z poruszonych tu wątków zawiera książka Historia brzydoty (Eco, 2007).

6 Świadczy o tym chociażby bezpośredni zwrot autorki do czytelnika zawarty w Zakończeniu na ostatniej stronie książki . 
wielowiekowej tradycji obrazowania śmierci, męczeństwa i cierpienia oraz popularnych zwłaszcza w epoce baroku wątków wanitatywnych.

Horror Szeligi jest zbiorem dwudziestu miniatur literackich opisujących tragiczne przypadki określane mianem „spraw”, jakie stały się udziałem siedemnastu różnych gatunków warzyw i owoców, a także pieczarek, słonecznika i pokrzyw, na co dzień traktowanych przez ludzi jako produkty spożywcze, a w omawianej książce uznanych za osobniki żywe z wszystkimi tego konsekwencjami. Bohaterowie ci, poddawani przez ludzi rozlicznym torturom, mają ciało, a także krewnych, przyjaciół i znajomych, przeżywają cały wachlarz emocji, odczuć i doznań: od strachu, lęku i trwogi, przez wstyd i zobojętnienie, po olbrzymią skalę bólu zadawanego na rozmaite sposoby i mściwą satysfakcję, kiedy samemu zada się cierpienie krzywdzicielowi. Kolejnych dwadzieścia historii-spraw staje się szczegółowymi aktami oskarżenia, relacjonującymi niecne procedery, jakich na roślinach dopuszcza się człowiek-oprawca, a które stają się niejednokrotnie podtytułami rozdziałów (np. Ukiszona żywcem, Podwójne morderstwo, Zbrodnia bez noża, Wyrywa serce kto sam jest bez serca). Stąd w tytule tego artykułu pojawiło się odwołanie do publikacji określanej w literaturze mianem pitawala, czyli zbioru sprawozdań sądowych (Głowiński, Kostkiewiczowa, Okopień-Sławińska, Sławiński, 1976/1989, s. 358). Pitawale z reguły charakteryzowało pewne uporządkowanie - najczęściej bowiem zbierały zdarzenia z określonego terenu, okresu lub o zbliżonych wątkach, z czasem te specyficzne antologie zaczęły zawierać głównie opisy przestępstw kosztem relacji z przebiegu rozpraw (Siewierski, 1979, s. 109-110). Drobiazgowość opisów zbrodni zawartych w Horrorze przypomina jednocześnie theatrum mortis obecne we współczesnej powieści kryminalnej. Oto próbka z rozdziału Sprawa Groszku. Zbrodnia w kołysce:

Dwa wielkie palce chwytają drugi Groszek, wyrywają go z kołyski, podnoszą. - Młodziutki - mówią usta żądne krwi - pyszny.

Palce zbliżają się do ust. Widać już białe zęby, czekające tylko, aby zacisnąć się na młodym ciele. Bracia i siostry patrzą na tę egzekucję. Ginie, rozgryziony przez lewą górną jedynkę (Szeliga, 2017, s. [21]).

Wskazanie lewej górnej jedynki jako narzędzia zbrodni natychmiast wywołuje w wyobraźni czytelnika przeskalowany obraz siekacza, który staje się gilotyną dla bezbronnej zielonej kuleczki groszku. Okrucieństwo przejawia się zatem

Skojarzenia ze „sprawami”, jakie były przedmiotem dochodzeń literackich detektywów, np. Sherlocka Holmesa w powieściach Arthura Conana Doyle’a, są tu jak najbardziej uzasadnione. 
nie tylko w samym celebrowaniu egzekucji, lecz także w akcie dokonywania jej na oczach bliskich. Książka zbudowana jest na dramatycznych okolicznościach, zindywidualizowanych w każdym z dwudziestu przypadków. Człowiek rośliny te ucina, ukręca im głowy, otwiera czaszki, wyrywa serca, upuszcza krew, gniecie, miażdży, dusi, skalpuje, wrzuca do wrzątku, obdziera ze skóry paseczek po paseczku, soli rany. Warzywa i owoce są krojone w drobne paseczki, plasterki, kosteczki, obierane ze skóry, przypiekane na czarno, upokarzane, ich brzuchy są krojone na pół, tracą przytomność, ich czerwone wnętrzności spływają po murze lub są wycinane i wyrzucane.

Horror wydaje się zatem zawierać wszystkie nieodzowne elementy: wywołuje uczucia lęku i grozy przez prezentowanie obrazów nieuchronnych śmierci kolejnych gatunków roślin i jednego grzyba oraz szczegółowe opisanie okoliczności ich tragicznych zgonów. W warstwie tekstowej natrafimy na takie sformułowania: „zbiorowy mord”, „miejsce ostatecznej kaźni”, „pachniało zbrodnią”, „brutalna masakra”, „realizacja morderczego planu”, „Czy zabić to za mało?" (Szeliga, 2017, s. [8], [12], [13], [17], [28]). To tylko kilka cytatów ukazujących determinację człowieka-oprawcy i potworność zdarzeń. W każdym rozdziale pojawiają się błyskające ostrzami noże różnej wielkości i rozmaitego przeznaczenia oraz inne narzędzia tortur: łyżki wydłubujące fragmenty ciała, tarki, miksery, drylownice, patelnie z rozgrzanym olejem, garnki z wrzątkiem, buchające gorącem piekarniki. Co ciekawe, w warstwie wizualnej rekwizyty te nie są jednak w ogóle eksponowane. Na ilustracjach nie ma żadnego z wymienionych wcześniej utensyliów kuchennych, czasami uda się dostrzec filigranowe widelczyki. Jako narzędzia zbrodni pojawiają się: szklany słój, beczka czy deska do krojenia - niebezpośrednio ewokujące grozę. Wyobrażenie tortur najczęściej stanowią płomienie, budzące jednoznaczne skojarzenia ikonograficzne z ogniem i mękami piekielnymi. Z rekwizytorni grozy zaczerpnięte zostały czaszki i kościotrupy (choć te ostatnie za sprawą miniaturowej skali owadów, do jakiej zostały sprowadzone, nie są chyba w stanie wzbudzić w czytelniku przerażenia). Wśród roślin-ofiar jest i dynia, która kojarzy się niewątpliwie z karnawałowym światem towarzyszącym tradycji celebrowania Halloween, rozpropagowanej przez kulturę amerykańską. Jabłko widoczne na stronie tytułowej także zostało ucharakteryzowane na czaszkę z głębokimi oczodołami i przerażającą szczęką. Krew pojawia się w ilustracjach sporadycznie, bo tylko niektóre z owoców (malina, czereśnia, porzeczka) i warzyw (marchew, burak) z natury swej mają sok w odpowiednim kolorze. Zwłaszcza burak broczy malowniczo w słoju, a zakrzepnięte krople jego soku/krwi u dołu stron stanowią wizualne akcenty rozkładówki zawierającej historię podwójnego morderstwa (w tym rozdziale ginie bowiem też cytryna). 
Analizując warstwę wizualną Horroru, dość szybko można spostrzec, że głównym źródłem inspiracji dla Dziubak nie jest wcale rekwizytorium Halloween ${ }^{8}$ czy filmów grozy, w których występują przerażające, wynaturzone postacie ludzkie, krwiożercze bestie, czarownice i wiedźmy, diabły i inne hybrydy, rozmaite potwory, nietoperze, pająki, węże i jaszczury, nocne ptaki, szczury oraz czarne koty. Bogatym źródłem inspiracji dla ilustratorki okazała się sztuka dawna z różnych epok, zwłaszcza z okresu baroku, w nieco mniejszym stopniu także manieryzmu. Już bowiem sam koncept, by animizować rośliny i nadać im cechy antropomorficzne, ma - jak się wydaje - rodowód manierystyczny. Eksponowanie warzyw na ciemnych neutralnych tłach, komponowanie ich w eleganckim ujęciu portretu (Pomidor, Słonecznik, Ananas, Karczoch) przywodzi natychmiast na myśl zaskakujące i dziwaczne, alegoryczne concetti Giuseppe Arcimbolda, malarza włoskiego czynnego na praskim dworze cesarza Rudolfa II Habsburga. Ich „cielesność” podkreśla także stosowany przez Dziubak silny modelunek światłocieniowy.

Ożywianie roślin w Horrorze nie jest przypadkiem odosobnionym. W bajkopisarstwie osobnicy ze świata fauny i flory (zwłaszcza drzewa i niektóre kwiaty) są bohaterami na równi z postaciami ludzkimi, a i przedmioty niejednokrotnie prowadzą fantastyczne, tajemne życie. Ten potencjał niesamowitości chętnie wykorzystywali też surrealiści. W tradycji plastycznej wątek antropomorfizacji natury oraz animizacji przedmiotów ma swoje liczne realizacje. Przykłady znajdziemy nie tylko, co do pewnego stopnia oczywiste, w ilustracjach książek dla dzieci. Warto tu wspomnieć chociażby Jeana Ignace’a Isidora Gérarda zwanego Grandvillem i jego dzieła graficzne zebrane w tomach Les métamorphoses du jour [Metamorfozy dnia] (1828-1829), Scènes de la vie privée et publique des animaux [Sceny z życia prywatnego i publicznego zwierząt] (1840-1841), Un autre monde [Inny świat] (1842) ${ }^{9}$. Inny twórca ważny dla omawianego tu wątku animizacji roślin to niewątpliwie Edward Lear ze swoją The Book of Nonsense [Księga nonsensu] (1846), a zwłaszcza Nonsense Botany

8 Warto w tym miejscu wspomnieć może o debiucie ilustratorskim Lane’a Smitha, który opracował graficznie Halloween ABC - 26 „strasznych” wierszyków Eve Merriam wydanych w 1987 roku przez Aladdin Paperbacks (imprint wydawnictwa Simon \& Schuster z Nowego Jorku). Jednak podobieństwa między obiema książkami znaleźć można jedynie w warstwie kolorystycznej, która opiera się na ciemnej tonacji, z dominacją brązów i czerwieni, mrocznym klimacie przedstawianych przestrzeni oraz motywie zanimizowanej dyni. Książka od 2002 roku (Macmillan, New York) ukazuje się pod tytułem Spooky ABC.

9 Więcej na temat prac Grandville’a piszę w innym tekście: Czterej panowie ilustratorzy, nie liczac zwierząt. XIX-wieczna grafika ilustracyjna we Francji i jej polskie echa (Wincencjusz-Patyna, 2008). 
(1888; oryginalnie prezentowane w latach $1870-1871)^{10}, \mathrm{w}$ której kwiaty mają fizjonomie i kończyny.

U Dziubak w Horrorze wszystkie rośliny mają twarze, a właściwie oczy i buzie, z rzadka nosy. Czytelnik widzi więc łzy, grymasy cierpienia, stężone bólem oblicza, opuszczone snem wiecznym powieki. Warzywa i owoce zostały wyposażone również w ręce i nogi, z wyjątkiem słonecznika, który został tu sprowadzony do swej promienistej głowy. Najsilniej zantropomorfizowanymi bohaterami są niewątpliwie: pieczarka, która jawi się jako malutka dziewuszka $\mathrm{z}$ ogromnym białym kapeluszem, i ananas $\mathrm{w}$ roli wodza plemiennego o ciele przyobleczonym w zbroję z charakterystycznych łusek. Animizacja w najmniejszym stopniu objęła pokrzywy, które właściwie otrzymały jedynie oczy, i to bardziej zwierzęce niż ludzkie. Osobniki-ofiary wzbudzają ciepłe uczucia, ponieważ ich kończyny przedstawione są w zdecydowanie mniejszej skali niż korpusy. Większość ciał bohaterów Horroru charakteryzuje przyjemna krągłość (np. brukselka, kapusta, pomidor, burak, dynia, jabłko), w przypadku groszku wręcz idealna, stąd komiczny efekt zrodzony z wyposażenia tych ciał w wyrostki w postaci krótkich, „dziecięcych” rączek i nóżek.

Wracając do inspiracji barokiem, ciekawe nawiązanie do sztuki tego okresu znajduje się już na okładce (patrz rysunek 1), która powstała na bazie ilustracji do rozdziału Sprawa Kalafiora. Kto daje życie i odbiera. Główny element przedstawienia to głowa kalafiora, przed którą tańczą w półokręgu warzywa (dynia, marchewka i pietruszka lub raczej skorzonera), owady (karaczan, mucha i osa), kościotrup i dwa ogryzki (komiczny ekwiwalent zwierzęcego szkieletu), wszystkie zaprezentowane w jednej skali. Motyw tańca w kręgu, zwłaszcza na ciemnym tle, niesie skojarzenia z wizerunkami tańca śmierci (danse macabre) znanego w ikonografii już od średniowiecza, a rozpowszechnionego w okresie baroku ${ }^{11}$. Subtelność rysunku Dziubak, kompozycja całości oraz pozy marchewki i pietruszki (lub może raczej skorzonery) pozwalają przywołać tu jako możliwą inspirację dla artystki jeden z najlepiej znanych polskich przykładów danse macabre, a mianowicie Taniec śmierci z kaplicy św. Anny z kościoła OO. Bernardynów na Stradomiu w Krakowie, datowany na czwartą ćwierć XVII wieku ${ }^{12}$. Wspomniane pozy warzyw przypominają $\mathrm{w}$ swej dynamiczności wiotkie szkielety $\mathrm{z}$ barokowego memento

\footnotetext{
10 Więcej o Learowskim nonsensie piszę w książce Odpowiedni dać rzeczy obraz. O genezie ilustracji książkowych (Wincencjusz-Patyna, 2019).

11 Ten temat szeroko zaprezentowany został np. w katalogu wystawy Tanieć Śmierci. Od późnego średniowiecza do końca XX wieku pod redakcją Ewy Ryżewskiej i Evy Schuster (2002).

12 Obraz olejny na płótnie o wymiarach $252 \times 210 \mathrm{~cm}$ o nieustalonym autorstwie.
} 


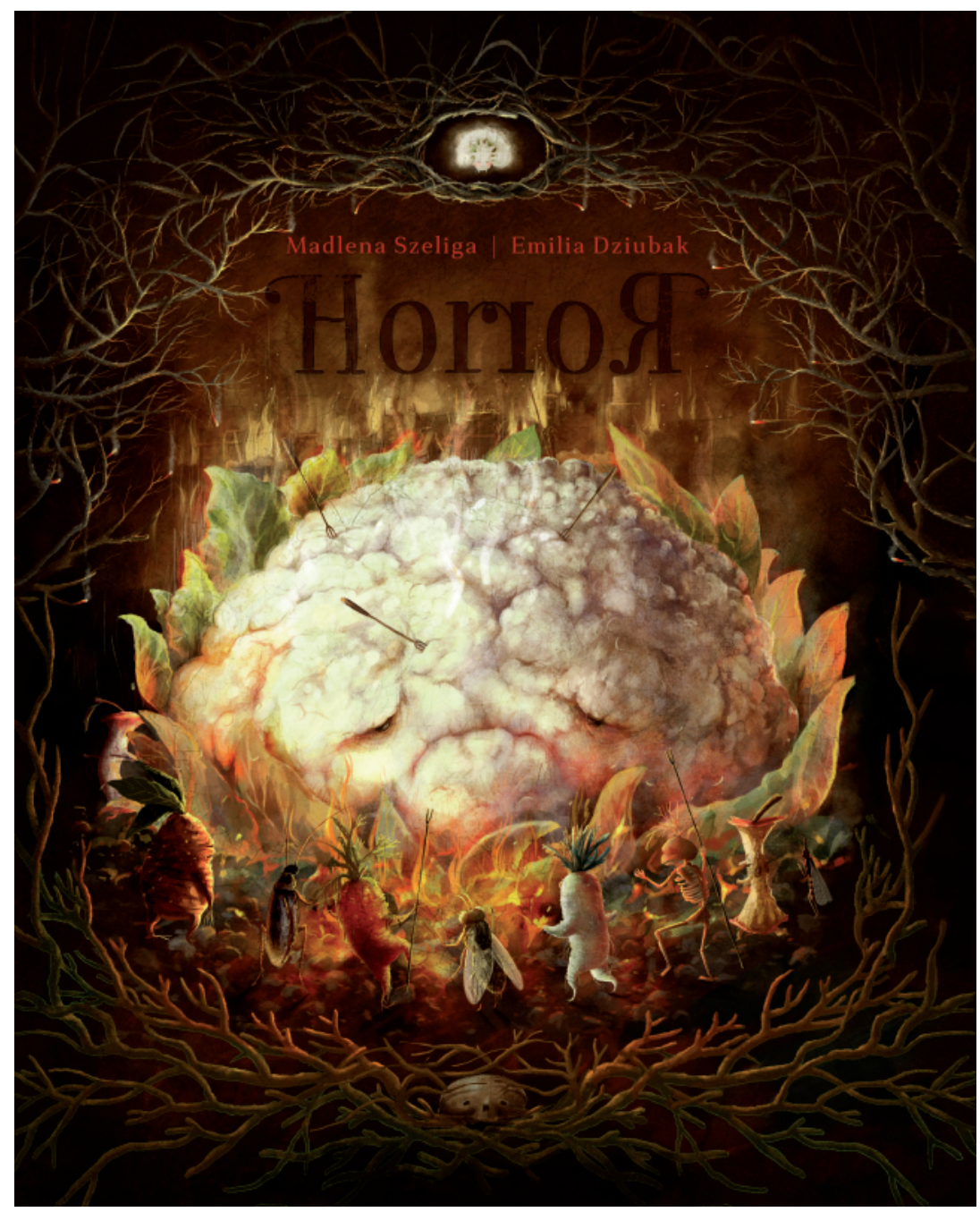

RYSUNEK 1. Emilia Dziubak, okładka książki Horror.

mori. Bordiurę złożoną z obrazków-medalionów bernardyńskiego tańca śmierci zastąpiła gęsta wić roślinna (kształtem trochę przypominająca nać marchwi). Układ wici zachowuje ścisłą symetrię, na osi została ona zaakcentowana w górnej części świecącym przekrojem główki kalafiora sugerującym jego „pośmiertne wniebowstąpienie”, a w dolnej wizerunkiem jakiegoś zszarzałego warzywa korzennego zaaranżowanego na kształt czaszki. Taka kompozycja całości przedstawienia nawiązuje też do barokowych epitafiów masowo fundowanych przez szlachtę i bogate mieszczaństwo w XVI i XVII wieku dla upamiętnienia zmarłych członków ich rodzin. Obramienia epitafiów 
były bardzo często akcentowane na osi (u dołu lub u góry) motywem trupiej czaszki, nierzadko na skrzyżowanych piszczelach, najbardziej oczywistym symbolem śmierci. Zabieg ten pojawia się i w innych ilustracjach w Horrorze. W ilustracji towarzyszącej historii kalafiora portret warzywa w mękach ukropu stracił bordiurę roślinną na rzecz półwieńca płomieni podgrzewających metalowy kocioł. Półokrąg tancerzy został rozbity na większą grupę pląsającą przed naczyniem i mniejszą, która miała na tyle odwagi, by wejść na krawędź kotła. Przekrojona główka kalafiora z okładki została tu zastąpiona fantomowym wyobrażeniem quasi-czaszki kalafiora, którego nie znajdziemy już u dołu kompozycji.

Kolejną wizualną referencją do sztuki nowożytnej są wyklejki zaprojektowane przez Dziubak na podobieństwo wzorów z barokowych tapet, w eleganckiej barwie grafitowej stanowiącej tło dla o ton jaśniejszego ornamentu. Motyw plecionki w układach symetrycznych, pasowych, złożonych z liści akantu, lilijek i margerytek, został też powtórzony na lewej stronie rozkładówki przedtytułowej, której strona prawa z quasi-widokiem tytułu książki zawiera tylko wizerunek małej dyni - jednej z bohaterek Horroru - na sepiowym poddruku. Kolor ten spaja całość książki aż po rozkładówkę z Zakończeniem. Rozkładówka tytułowa na lewej stronie zawiera kolumnowo zaprojektowany kolofon, po prawej cienka prostokątna ramka zwraca uwagę na autorki i tytuł oraz buduje nastrój za sprawą czaszkopodobnego wizerunku jabłka, które w pierwszej chwili może być omyłkowo wzięte za dynię. Ten zabieg nie jest przypadkowy (o konotacjach dyni była już mowa), a służy mu celowe powiększenie jabłka, podkreślone też rozmiarem muchy wędrującej po jego wierzchu, spomarańczowienie owocu w wyniku procesów gnilnych, pomarszczenie skórki oraz wykrojenie w jabłku oczodołów i zaznaczenie przerażającej górnej szczęki. Osadzone w pustej przestrzeni jabłko zostanie powtórzone przez Dziubak, tym razem na tle pejzażu i w złoconej ramie, w rozdziale Sprawa Jabłka. Zbrodnia bez noża (patrz rysunek 2).

Dwie kolejne rozkładówki (ze spisem treści, a właściwie Spisem przykrych zdarzeń i Wstępem) zaprojektowane są bardzo oszczędnie i elegancko. Wizualnie porządkują je cienkie ramki, a w charakterze winiety pojawia się miniaturowy wizerunek ziarenka groszku, subtelnie wprowadzając kolejnego bohatera tragicznego.

Projekt zasadniczej części książki opiera się na naprzemiennym układzie rozkładówek tytułowych anonsujących kolejną zbrodnię oraz rozkładówek tekstowych zawierających kolejne makabryczne historie. Ten układ podkreślony został kontrastem ciemnej tonacji rozkładówek tytułowych i tonacji jasnej, sepiowej, oszczędnie wzbogaconej kolorem - rozkładówek tekstowych. 


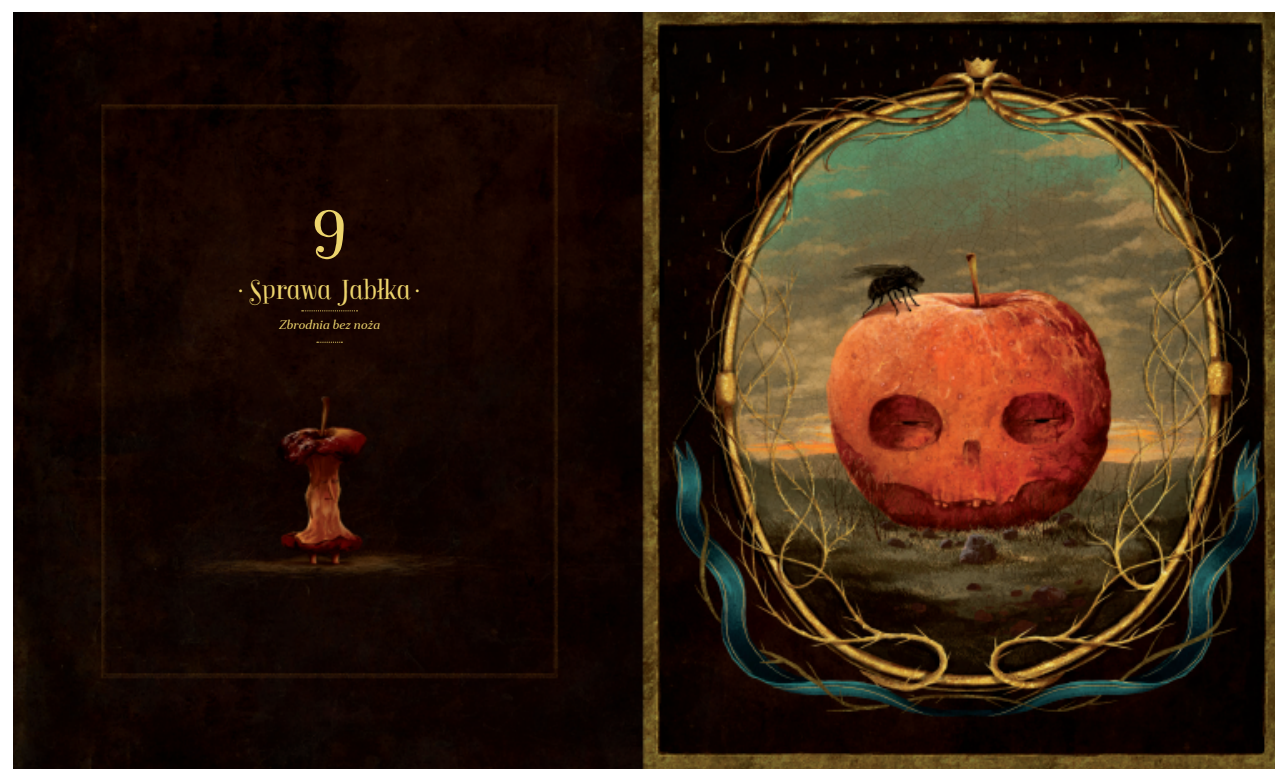

RYSUNEK 2. Emilia Dziubak, ilustracja do rozdziału Sprawa Jabłka. Zbrodnia bez noża.

Dla urozmaicenia całości projektu w kilku przypadkach rozkładówki tekstowe otrzymały szerokie ciemne obramienia, niejednokrotnie z rozbudowanym ornamentem. Lewa strona rozkładówki tytułowej to numer rozdziału, nazwa sprawy oraz umieszczona poniżej winieta zapoznająca czytelnika z bohaterem opowiadania. Prawa strona rozkładówki tytułowej, to - rzec by można - ilustracja właściwa, całostronicowa, niejednokrotnie w specjalnym obramieniu, którego kształt czasami dodatkowo nawiązuje do ram dawnego malarstwa (zaokrąglone naroża, łukowe zamknięcie od góry, owal). Rozkładówki tekstowe ujmują bloki tekstu w osobne symetrycznie zakomponowane bordiury, zawierające skorelowane treściowo elementy, najczęściej przetworzone części rośliny, której dotyczy konkretna historia. Najwięcej jest tu zatem łodyg, pędów, liści i owocników. Czasami bordiura wydaje się wprost zaczerpnięta z dzieł sztuki barokowej (ram obrazów, zdobników graficznych, obramień epitafiów i tablic inskrypcyjnych) z wkomponowanymi w nią elementami warzywa czy owocu, jak w Sprawie Marchwi. Soleniu ran, w której złocony mięsisty akant został przepleciony systemem korzennym szaro-błękitnych, obumarłych warzyw (patrz rysunek 3.). W tę bogatą ramę wkomponowano na osi obrazki-medaliony przedstawiające życie - pełna witalności nać wystająca z gruntu, i śmierć marchewki - korzeń spoczywający na ziemi, na której rozlała się plama krwistego soku. 


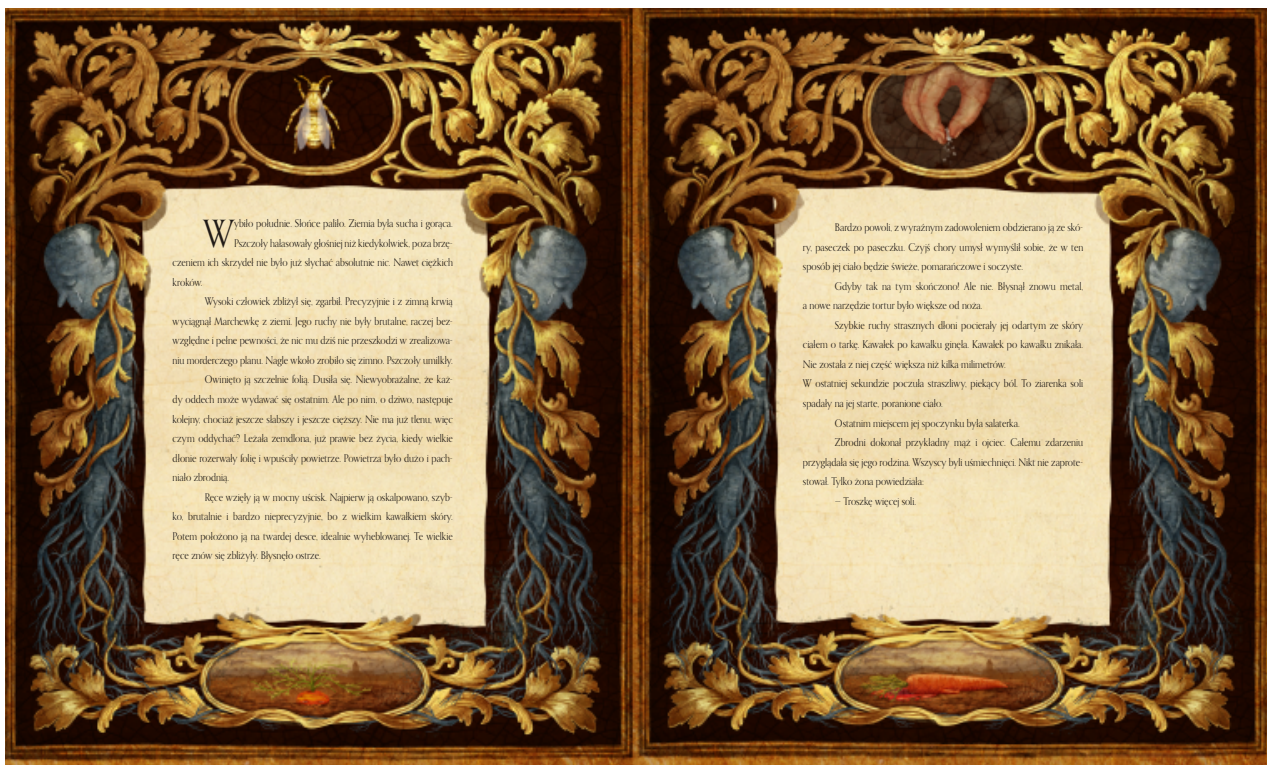

RYSUNEK 3. Emilia Dziubak, ilustracja do rozdziału Sprawa Marchwi. Solenie ran.

Warto zwrócić uwagę na te miniatury, bowiem zawierają nie tylko motywy symboliczne odnoszące się jednocześnie do konkretnej historii (w przypadku marchewki np. jest to pszczoła towarzysząca jej za beztroskiego życia), lecz także przedstawienia narzędzia lub sceny zbrodni (tu jest to kobieca dłoń sypiąca sól). We wszystkich ilustracjach widać doskonałe wyczucie formy u Dziubak, jak choćby w liściu kapusty, który przybiera kształt główki barokowego putta - „dzieciuka”13 (patrz rysunek 4), czy we wniebowziętym ziemniaku, którego łęty układają się na kształt poroża, a cały wizerunek kojarzy się przez to z myśliwskim trofeum.

W historii o cebuli pojawił się detal płaczącego oka, jakby zacytowany z wizerunków Mater Dolorosa pędzla Hansa Memlinga lub Dirka Boutsa z końca XV wieku albo może innej płaczącej niewiasty (patrz rysunek 5).

Najczęściej miniatury te odnoszą się jednak do opozycji życia i śmierci. I tak wizerunek jędrnego młodego kalafiora zestawiony jest ze ślimakiem, winnego grona - z rodzynką, zaś słońce o kształcie plastra ananasa - $\mathrm{z}$ wizerunkiem soczystego żółtego owocu przeciętego na pół (patrz rysunek 6). Te małe

13 „Dzieciuk” jest bardziej swojską nazwą dla pucołowatych amorków znanych powszechnie w sztuce jako putta, odnoszącą się zwłaszcza do późnonowożytnej rzeźby z Kresów (np. Gębarowicz, 1986, s. 6). 


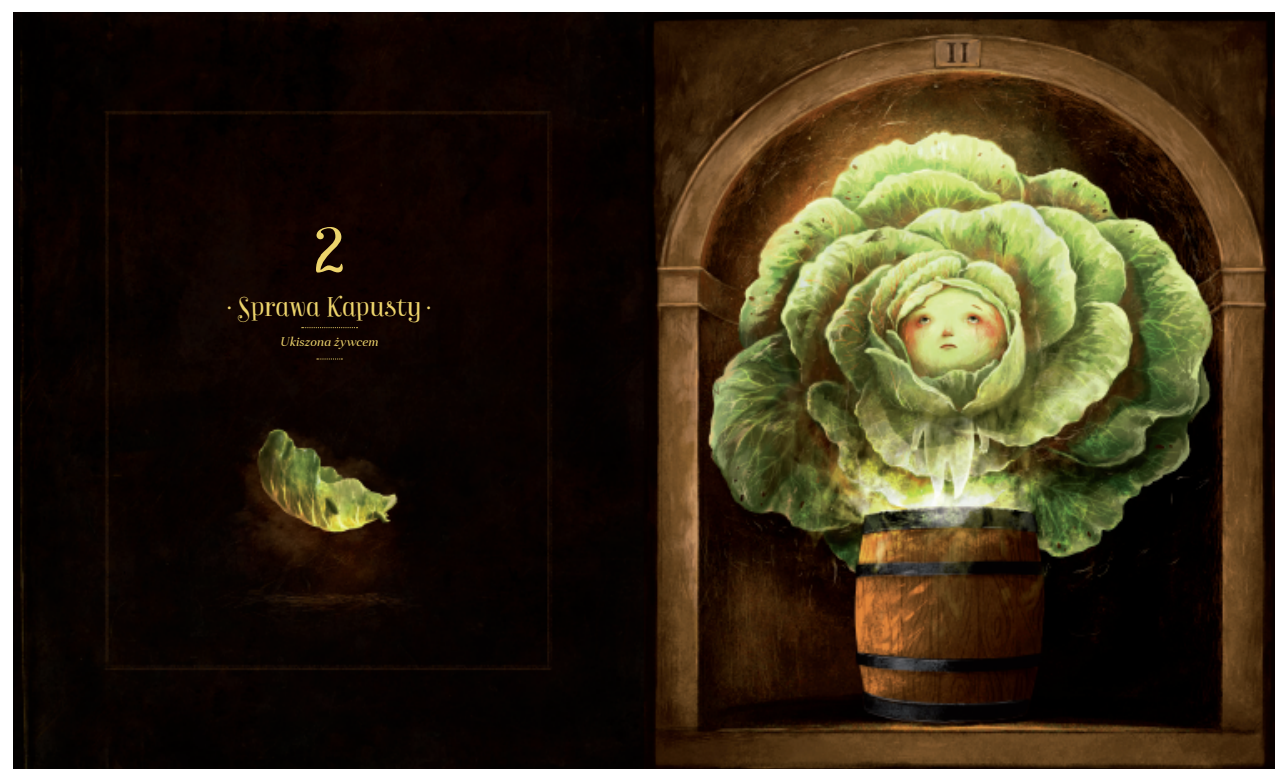

RYSUNEK 4. Emilia Dziubak, ilustracja do rozdziału Sprawa Kapusty. Ukiszona żywcem.

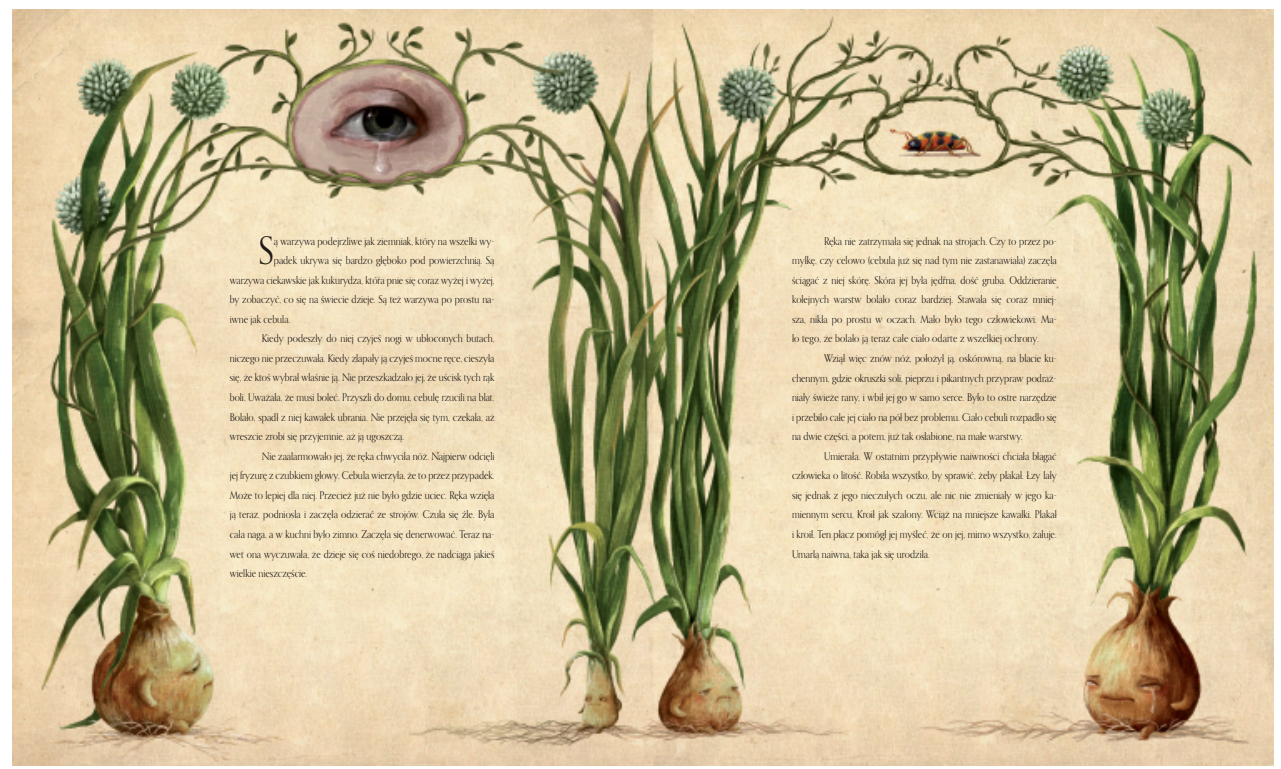

RYSUNEK 5. Emilia Dziubak, ilustracja do rozdziału Sprawa Cebuli. Kilka łez nic nie znaczy. 


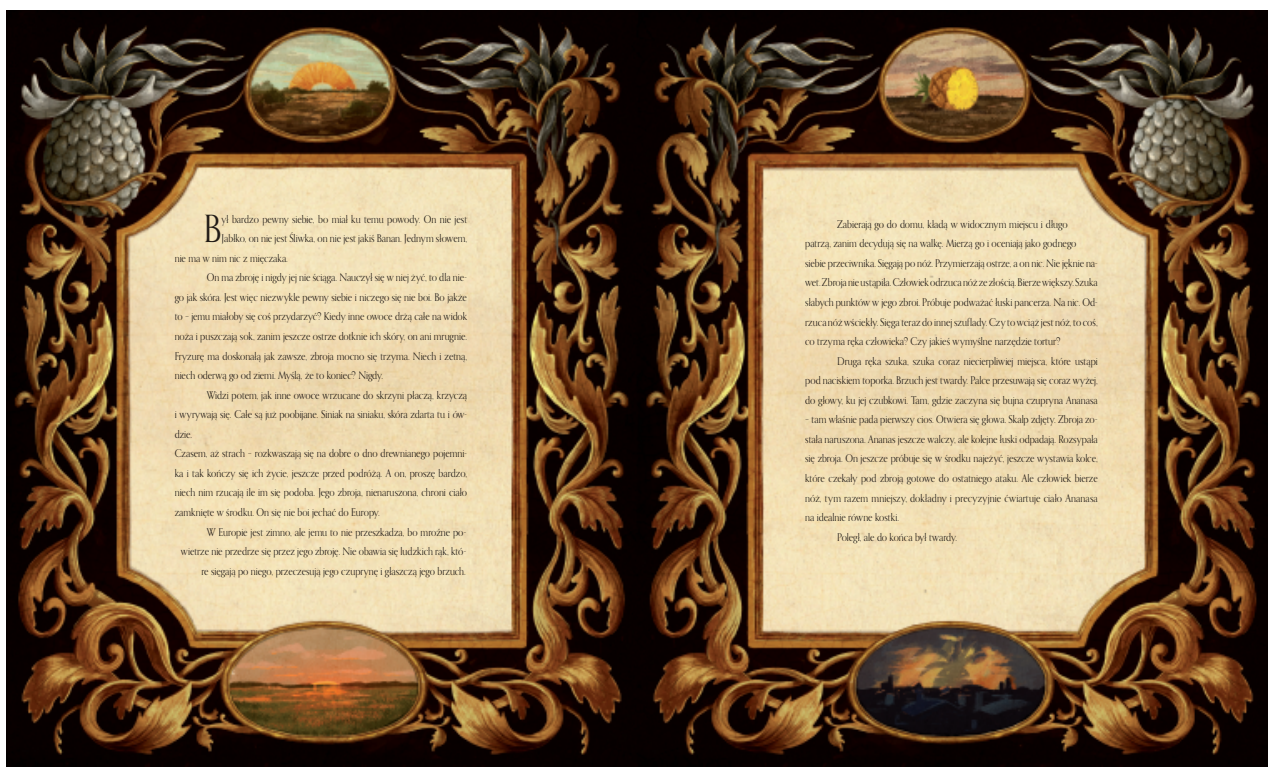

RYSUNEK 6. Emilia Dziubak, ilustracja do rozdziału Sprawa Ananasa. I zbroja nie ochroni.

obrazki, podobnie jak starannie zakomponowane bordiury, zdają się dla Dziubak tak samo ważne jak całostronicowe kompozycje.

W ilustracjach Dziubak do Horroru wyraźne są rozmaite odwołania do arcydzieł europejskiego malarstwa barokowego, z uwagi na tematykę książki przede wszystkim do martwych natur (np. Sterling, 1985/1998). Wśród inspiracji na pierwszym miejscu należy wymienić martwe natury Juana Sáncheza de Cotána, który w swych obrazach eksponuje w intensywnym światłocieniu warzywa i owoce, wydobywając je z głębokiej czerni tła. Reprezentatywnym przykładem może tu być Martwa natura z pigwą, kapustą, melonem i ogórkiem z 1602 roku $^{14}$. Ważny wydaje się także Francisco de Zurbarán, m.in. ze swoimi bodegonami, ale i za sprawą obrazu olejnego Agnus Dei (ok. 1635-1640, Prado), którego minimalizm w warstwie przedstawieniowej współgra $\mathrm{z}$ dążącą do oszczędnej dyspozycją kolorystyczną: biel runa Baranka Bożego oraz czerni i szarości tła. U Dziubak czytelnik ujrzy marchewkę spoczywającą płasko na równomiernym, ciemnym tle, która na swój sposób jest asocjacją wizualną z przejmującym obrazem Hiszpana (patrz rysunek 3). Także martwe natury pędzla Caravaggia i całej plejady Holendrów, zwłaszcza specjalizujących się w tematyce kulinarnej i wanitatywnej, stanowią przekonujący punkt

14 Obraz olejny o wymiarach 68,9 x 84,5 cm, w zbiorach Museum of Art w San Diego. 
odniesienia dla kompozycji malarskich Dziubak. Artystka konsekwentnie umieszcza w nich różne gatunki owadów - ważki, stonki, pszczoły, osy, muchy. Z jednej strony urealniają mikroświat ukryty między źdźbłami trawy, a z drugiej są częstymi motywami martwych natur typu vanitas jako symbole odnoszące się do procesów rozkładu, a zatem do śmierci, przemijania. Wątki są także podkreślane przez pożółkłe, zwiędłe lub zeschnięte liście sygnalizujące kres wegetacji, użyte na przykład w Sprawie Słonecznika. Torturowanie wciaga i Sprawie Winogron. Horrorze przemijania.

Emilia Dziubak, absolwentka grafiki poznańskiej Akademii Sztuk Pięknych ${ }^{15}, \mathrm{z}$ temperamentu jest jednak przede wszystkim malarką. Choć jej prace powstają w całości na tablecie ${ }^{16}$, sprawiają wrażenie pieczołowicie wykonanych, drobiazgowo namalowanych pędzlem z sobolowego włosia. Wyraźny modelunek światłocieniowy, miękkie przejścia tonalne, celowo użyty w niektórych ilustracjach rysunek rzekomej siatki spękań werniksów, tzw. krakelury, charakterystyczny dla starych dzieł wykonanych techniką olejną - kierują skojarzenia odbiorcy w stronę dawnego malarstwa. Tych tropów uda się czytelnikowi być może odnaleźć jeszcze więcej. W „morzu” czerwonego soku wygotowywanego z porzeczek, malin i jabłka widać pewne podobieństwa do malarstwa marynistycznego Iwana Ajwazowskiego, w ujęciu „wniebowzięcia” kapusty (patrz rysunek 4) pobrzmiewają echa wizerunków świętych męczennic z okresu późnego renesansu (Tycjan) lub wizerunków Marii Immaculaty z baroku (np. pędzla Bartolomé Estebana Murilla). Z kolei ilustracje, w których pojawia się fragment człowieka (dłoń w Sprawie Marchwi - rysunek 3 i w Sprawie Pieczarek - rysunek 7 oraz noga z butem w Sprawie Cebuli - rysunek 5), ze względu na grę skalą przypominają rozwiązania kompozycyjne, jakie Dziubak stosowała w ilustracjach swojego autorstwa do serii książek o przygodach Pożyczalskich spisanych przez Mary Norton (1952/2012, 1955/2014a, 1959/2014b, 1961/2015a, 1982/2015b).

Podsumowując, należy uznać, że okrucieństwo, dosadność, drobiazgowość w opisywaniu cierpień doznawanych przez bohaterów książki Horror Madleny Szeligi zostaje złagodzona eleganckimi, potraktowanymi bardzo dekoracyjnie, subtelnymi konterfektami roślin (i jednego grzyba) post mortem. Ilustratorka nie epatuje okrucieństwem, a obrazy śmierci wyraźnie estetyzuje, odwołując się do stylistyki manierystycznej i barokowej. Dziubak śmiało czerpie z dziedzictwa sztuki, ale i z kultury epoki baroku, która spopularyzowała wątki wanitatywne, niekoniecznie łącząc je z obrzędami funeralnymi. Tekst

15 Obecnie Uniwersytet Artystyczny w Poznaniu.

16 O procesie twórczym ilustratorki pisze Sebastian Frąckiewicz (2017). 


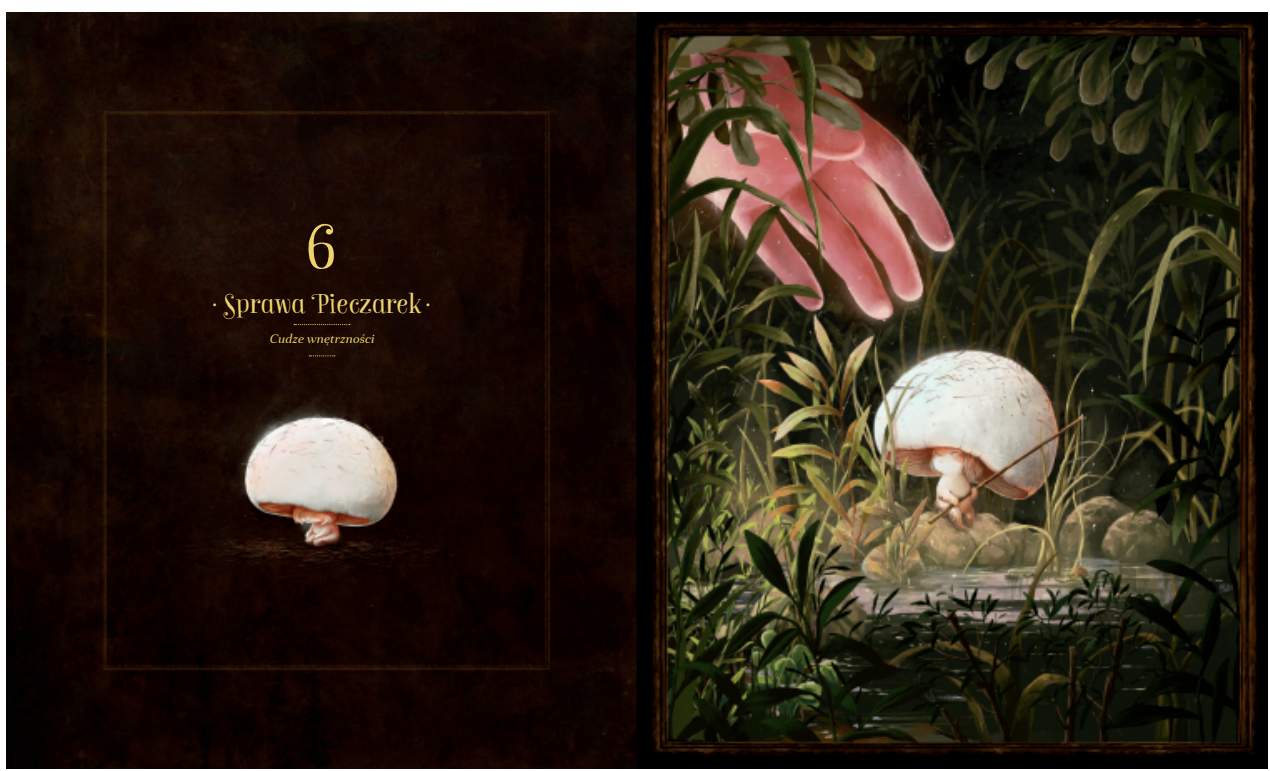

RYSUNEK 7. Emilia Dziubak, ilustracja do rozdziału Sprawa Pieczarek. Cudze wnętrzności.

książki oparty na przewrotnym koncepcie: „A co[,] gdyby warzywa naprawdę miały uczucia?" (s. [5]) brać przecież należy w wyraźny cudzysłów. Tym bardziej adekwatne wydają się wysmakowane, dosłownie i w przenośni, ilustracje Emilii Dziubak.

\section{Bibliografia}

Dieckmann, E., Grau, A. (prod.), Murnau, F. W. (reż.). Nosferatu, eine Symphonie des Grauens [Nosferatu - symfonia grozy] [film]. Niemcy: Prana Film.

Eco, U. (red.). (2007). Historia brzydoty (J. Czaplińska i in., tłum.). Poznań: Rebis.

Frąckiewicz, S. (2017). Emilia Dziubak. Umysł stuprocentowego introwertyka. W: Ten łokieć źle się zgina. Rozmowy o ilustracji (s. 11-52). Wołowiec: Czarne.

Gaudreault, A. (1995). Teatralność, narracyjność, trickowość. Oceniając kino Georges'a Mélièsa. W: M. Hendrykowska (red.), W cieniu braci Lumière. Szkice o początkach kina (s. 24-35). Poznań: Ars Nova.

Gębarowicz, M. (1986). Prolegomena do dziejów lwowskiej rzeźby rokokowej. Artium Questiones, 3, 5-46.

Głowiński, M., Kostkiewiczowa, T., Okopień-Sławińska, A., Sławiński, J. (1989). Słownik terminów literackich. Wrocław, Warszawa, Kraków, Gdańsk, Łódź: Zakład Narodowy im. Ossolińskich. (wyd. oryg. 1976). 
Grimm, W., Grimm, J. (1812). Die Kinder- und Hausmärchen. Gesammelt durch die Brüder Grimm. Berlin: Realschulbuchhandlung.

Grimm, W., Grimm, J. (1815). Die Kinder- und Hausmärchen. Gesammelt durch die Brüder Grimm. Zweiter Band. Berlin: Realschulbuchhandlung.

Gryglewicz, T. (1984). Groteska w sztuce polskiej XX wieku. Kraków: Wydawnictwo Literackie.

Has-Tokarz, A. (2010). Horror w literaturze współczesnej i filmie. Lublin: Wydawnictwo UMCS.

Hendrykowska, M. (1998). Georges Méliès. W: A. Kołodyński, K. J. Zarębski (red.), Historia kina. Wybrane lata (s. 24-32). Warszawa: „Kino”.

Kłys, T. (2012). Film niemiecki w epoce wilhelmińskiej i weimarskiej. W: T. Lubelski, I. Sowińska, R. Syska (red.), Historia kina. Tom 1. Kino nieme (s. 408-423). Kraków: TAiWPN Universitas.

Lear, E. (1846). A book of nonsense. London: Routledge.

Lear, E. (1888). Nonsense books. Boston: Little, Brown.

Lubelski, T. (2012). Lumière i Méliès: fotograf i iluzjonista inicjują kinematograf. W: T. Lubelski, I. Sowińska, R. Syska (red.), Historia kina. Tom 1. Kino nieme (s. 111-136). Kraków: TAiWPN Universitas.

Merriam, E. (1987). Halloween ABC. New York: Aladdin.

Norton, M. (2012). Kłopoty rodu Pożyczalskich (M. Wisłowska, tłum.). Warszawa: Dwie Siostry. (wyd. oryg. 1952).

Norton, M. (2014a). Pożyczalscy ida w świat (M. Wisłowska, tłum.). Warszawa: Dwie Siostry. (wyd. oryg. 1955).

Norton, M. (2014b). Pożyczalscy na wyspie (M. Wisłowska, tłum.). Warszawa: Dwie Siostry. (wyd. oryg. 1959).

Norton, M. (2015a). Pożyczalscy w przestworzach (M. Wisłowska, tłum.). Warszawa: Dwie Siostry. (wyd. oryg. 1961).

Norton, M. (2015b). Pożyczalscy pomszczeni (M. Wisłowska, tłum.). Warszawa: Dwie Siostry. (wyd. oryg. 1982).

Pieńkos, A. (2000). Okropności sztuki. Nowoczesne obrazy rzeczy ostatecznych. Gdańsk: Słowo/Obraz Terytoria.

Ryżewska, S., Schuster, E. (red.). (2002). Taniec Śmierci. Od późnego średniowiecza do końca XX wieku [katalog wystawy]. Szczecin: Zamek Książąt Pomorskich.

Siewierski, J. (1979). Powieść kryminalna. Warszawa: Krajowa Agencja Wydawnicza.

Slany, K. (2016). Groza w literaturze dziecięcej. Od Grimmów do Gaimana. Kraków: Wydawnictwo Naukowe UP.

Sterling, C. (1998). Martwa natura. Od starożytności do XX wieku (J. Pollakówna, W. Dłuski, tłum.). Warszawa: Wydawnictwa Artystyczne i Filmowe, WN PWN. (wyd. oryg. 1985). 
Szeliga, M. (2017). Horror. Kraków: Gereon.

Walpole, H. (1976). Zamczysko w Otranto. Opowieść gotycka (M. Przymanowska, tłum.). Kraków: Wydawnictwo Literackie. (wyd. oryg. 1764).

Wincencjusz-Patyna, A. (2008). Czterej panowie ilustratorzy, nie licząc zwierząt. XIX-wieczna grafika ilustracyjna we Francji i jej polskie echa. Quart, 2(8), s. 18-45.

Wincencjusz-Patyna, A. (2019). Odpowiedni dać rzeczy obraz. O genezie ilustracji ksiązkowych. Wrocław: ASP im. Eugeniusza Gepperta. 